Western University

Scholarship@Western

Political Science Publications

Political Science Department

2009

THE NEW U.S. DOCTRINE OF PREEMPTIVE WARFARE AND ITS IMPLICATIONS FOR

NUCLEAR DETERRENCE AND

DISARMAMENT

Erika Simpson

Political Science, simpson@uwo.ca

Follow this and additional works at: https://ir.lib.uwo.ca/politicalsciencepub

Part of the Political Science Commons

Citation of this paper:

Simpson, Erika, "THE NEW U.S. DOCTRINE OF PREEMPTIVE WARFARE AND ITS IMPLICATIONS FOR NUCLEAR DETERRENCE AND DISARMAMENT" (2009). Political Science Publications. 80.

https://ir.lib.uwo.ca/politicalsciencepub/80 
Erika Simpson, “The New U.S. Doctrine of Preemptive Warfare and its Implications for Nuclear Deterrence and Disarmament" in David Krieger, ed., The Challenge of Abolishing Nuclear Weapons (Transaction Publishers: Piscataway, NJ.) 2009, chapter 9, pp.?

\section{THE NEW U.S. DOCTRINE OF PREEMPTIVE WARFARE AND ITS IMPLICATIONS FOR NUCLEAR DETERRENCE AND DISARMAMENT \\ by \\ Erika Simpson}

\section{INTRODUCTION: THE “NEW" U.S. PREEMPTIVE DOCTRINE OF 2002 AND 2006}

The U.S. Nuclear Posture Review (NPR), leaked to the media in early 2002, allowed for the use of nuclear weapons in three scenarios:

1. against targets able to withstand attacks by non-nuclear weapons (such as underground bunkers);

2. in retaliation for an attack with nuclear, biological, or chemical weapons;

3. and "in the event of surprising military developments," such as an "Iraqi attack on Israel or its neighbors, or a North Korean attack on South Korea, or a military confrontation over the status of Taiwan."

In that same year, the Bush administration declared in its National Security Strategy (NSS): "Given the goals of rogue states and terrorists, the United States can no longer solely rely 
on a reactive posture as we have in the past. . . To forestall or prevent such hostile acts the U.S. will, if necessary, act preemptively."2

The increased or "new" emphasis on preemptive doctrine was strongly criticized by politicians and scholars, but the government reasserted essentially the same policy in its 2006 National Security Strategy:

The United States has long maintained the option of preemptive actions to counter a sufficient threat to our national security. The greater the threat, the greater is the risk of inaction - and the more compelling the case for taking anticipatory action to defend ourselves, even if uncertainty remains as to the time and place of the enemy's attack. To forestall or prevent such hostile acts by our adversaries, the United States will, if necessary, act preemptively. ${ }^{3}$

As Daryl Kimball, the executive director of the Washington-based Arms Control Association, points out: “Actually they're trying to better market their national security strategy. They saw the policy debate, the polls, and the international reaction to their plan, so they may have learned a few lessons from the school of hard knocks but they haven't switched gears and decided to work in international coalitions."

The United States' doctrine of preemptive warfare evidently alarms members of the international arms control and disarmament community. This article considers the problems and implications of the "new" U.S. preemptive doctrine. It argues that the doctrine cannot continue to be credible or sustainable over the long-term. Civil society groups are pressuring North Atlantic Treaty Organization (NATO) governments to reopen the door to further engagement on these 
questions. In fact, the emerging U.S. doctrine of preemptive warfare is proving to be problematic, even amongst its chief proponents in Washington and at NATO headquarters in Brussels. It needs formal review by the United States and its allies within NATO, probably at the same time as the alliance reconsiders its traditional "Strategic Concept." Recent interviews by the author in Washington and at NATO headquarters indicate that policy makers may review the inconsistencies between the United States' reliance upon nuclear deterrence and NATO's adherence to the Strategic Concept in conjunction with the alliance's sixtieth anniversary celebrations in 2009.

\section{PROBLEMS AND IMPLICATIONS OF PREEMPTIVE DOCTRINE}

The U.S. development of more nuclear weapons-related technologies for fighting limited nuclear wars on the battlefield, and in space, will make their use more, not less likely. Threatening to use preemptive nuclear retaliation against terrorist groups or rogue states makes nuclear war more "credible" now than it has been since the Cuban missile crisis. While it is certainly true that Americans cannot sit idly by while their security is undermined, the route they are taking — asserting nuclear credibility—will result in a more insecure world with a greater, not less, likelihood of nuclear war. The Western alliance's concepts of nuclear deterrence and nuclear preemption need to move away from the traditional notion of "defending" against threats_-such as strategic or tactical nuclear weapons - as well as the newer notion of "offensively" using preemptive nuclear strikes. Instead, the emphasis must be placed on achieving "minimal” nuclear deterrence and, eventually, nuclear abolition. 
If the U.S. continues on its present trajectory-threatening to respond or preempt a nuclear, biological, or chemical attack possibly with nuclear weaponry-it will incite an arms race where many states will seek to deter or preempt using all types of new weapons, including enhanced radiation weapons, space control satellites, and nuclear-survivable communications systems. The costs for the world will be enormous as countries compete to design weapons for use against possibly undeterrable terrorists, on rogue state battlefields, and in outer space. As a statement on nuclear weapons policy issued by the board of the Nuclear Age Peace Foundation pointed out: "It is the U.S. insistence on retaining a nuclear weapons option that sets the tone for the world as a whole. . . In this post-September $11^{\text {th }}$ climate, the United States has suddenly become for other governments a country to be deterred rather than, as in the Cold War, a country practicing deterrence to discourage aggression by others."

\section{THERE ARE NO GUARANTEES THAT THREATS OF RETALIATION OR PREEMPTION SUCCEED IN} PREVENTING ATTACK

The United States' allies need to ask themselves in the months leading up to NATO's sixtieth anniversary and the 2010 Non-Proliferation Treaty (NPT) Review Conference whether nuclear weapons protect them by deterring potential aggressors from attacking. During the Cold War, strategists assumed that by threatening massive retaliation, nuclear weapons could credibly prevent an enemy from attacking. September $11^{\text {th }}$ demonstrated there are no guarantees that the threats of preemption or retaliation will succeed in preventing an attack-indeed, it may be difficult to retaliate against a substate opponent, like a terrorist group. Moreover, traditional arguments against classical deterrence still hold true. There are many ways that deterrence and/or 
preemption could fail, including misunderstanding, miscalculation, poor communication, irrational leadership, and accident. ${ }^{6}$

But there is little likelihood that hard-line strategists will come to reject the doctrine of deterrence in its various permutations. Will this generation of strategic decision makers need to retire or die before the Great Powers, particularly American policymakers, relinquish their convictions about deterrence? Many decision makers in the upper echelons of the North American policy debate continue to surmise that nuclear deterrence has succeeded, and will continue to succeed, because there was no large-scale nuclear war between the U.S. and the USSR during the Cold War. Bureaucratic recalcitrance also prevents changes in defense policy that defy even the best high-level intentions. ${ }^{7}$

\section{YET THE BUSH ADMINISTRATION DECIDED TO THINK CRITICALLY ABOUT MUTUAL ASSURED DESTRUCTION}

Recent evidence indicates that, in the wake of the September $11^{\text {th }}$ crisis, decision makers in the highest echelons of American decision making (including President Bush and his closest advisors) began to doubt the efficacy of deterrence and think more critically about this strategy. Clearly the President held traditional assumptions about deterrence before the attack on America. Five minutes after American Airlines Flight 77 slammed into the Pentagon, he reached his vice president, Dick Cheney. "We're at war," Bush said. When the president hung up, he turned to some of his staff on Air Force One who had heard his comment to Cheney. "That's what we're paid for boys. We're going to take care of this. And when we find out who did this, they're not 
going to like me as president. Somebody is going to pay." A few minutes later, Bush said to Cheney, "We're going to find out who did this and we're going to kick their asses." 8

Barely a month later, Bush and Cheney were far less certain about whether Osama bin Laden would be deterred by America's threat to reserve the right to use any means at its disposal to respond to any use of weapons of mass destruction. At a National Security Council meeting on October 9, Vice President Cheney and Secretary of Defense Donald Rumsfield discussed the possibility that bin Laden (whom they referred to as UBL) might have weapons of mass destruction. "UBL might not be deterrable," said Cheney. "Well," the president said, "sponsoring nations of UBL, those that support him, might have some influence with him. Should we send some messages, private or public?" "We need to think some more about this," said Rumsfeld. ${ }^{9}$

Unfortunately, their thinking led them to quickly and closely embrace the doctrine of preemptive warfare. Tellingly, during the second presidential debate with John Kerry, George Bush argued for stronger offenses because terrorists only need to succeed once for defenses to fail—and defenses cannot necessarily be fail-safe one-hundred percent of the time. ${ }^{10}$ It seems that strong advocates of deterrence from the "New Right," like Bush, Cheney, and Rumsfeld, came to reluctantly recognize that deterrence could fail to work with substate actors and a more credible alternative was needed. They chose to reissue the National Security Strategy of 2002 in essentially its same form in 2006, despite widespread international criticism.

THE DOCTRINe OF PREEMPTIVE NUCLEAR WAR CANNOT CONTINUE TO BE CREDIBLE OR SUSTAINABLE OVER THE LONG-TERM 
Nevertheless, the doctrine of preemptive nuclear war promises to be neither credible nor sustainable over the long-term. Especially as attitudes toward nuclear weapons change in the future, it will become ever more difficult for leaders to credibly threaten nuclear use. The images of Hiroshima and Nagasaki remain etched on the mindsets of decision makers. ${ }^{11}$ Future discussions about the merits and demerits of adopting U.S. preemptive doctrine (perhaps as NATO's official policy) will no doubt be marred by massive disagreement and vocal dissension. That is why European diplomats wisely avoid the doctrinal discussions so eagerly welcomed by a few American diplomats at NATO. Indeed, indications are that the European and Canadian allies of the United States in NATO will avoid any review or discussion of NATO's nuclear policy in favor of sustained attention to Afghanistan, Iraq, and/or peacekeeping in the Balkans. They will hope the informed public will be distracted from considering deeply disturbing questions surrounding possible nuclear war. ${ }^{12}$

\section{CIVIL SOCIETY GROUPS ARE PRESSURING NATO GOVERNMENTS TO REOPEN THE DOOR TO FURTHER ENGAGEMENT ON THESE QUESTIONS}

It will be left up to members of the domestic public — particularly NGOs that are active on nuclear disarmament issues - to pressure NATO governments to reopen the door to further engagement on these questions. While NATO conducted a review process of its reliance on nuclear weapons in 1999-2000, its reexamination of the Strategic Concept simply reaffirmed its central tenet—that nuclear weapons are "essential."

Although NATO decision makers assert that this review—-the paragraph 32 process - is

finished, some NATO governments are being pressured (among others by the International 
Pugwash Conferences, the Canadian Pugwash Group, the Canadian Coalition for Nuclear Responsibility, and Project Ploughshares) to reopen the door to further engagement on the question. ${ }^{13}$ Civil society groups in all the NATO countries need to ask themselves why NATO's nuclear force posture has not been reviewed since 1999, and is essentially the same in policy terms as it has been since $1967 .{ }^{14}$ Considering the sea-changes to the international security environment since the end of the Cold War and 9/11, NATO's status quo stance is not contributing anything of political or military value to its credibility.

\section{BRITISH POLICY RELIES UPON ITS INDEPENDENT NUCLEAR DETERRENT BUT SHIES AWAY FROM DECLARING PREEMPTIVE USE}

Sometime after the leak of the U.S. Nuclear Posture Review, a widely-reported speech by Britain's Defense Secretary Geoffrey Hoon appeared to echo the Bush administration's stance: "They [rogue states] can be absolutely confident that in the right conditions we would be willing to use our nuclear weapons." Moreover, Hoon told a parliamentary defense committee, "Although the Cold War is over, we face new, emerging threats. It is right that we consider all possible elements of a comprehensive strategy." ${ }^{, 15}$ Hoon also later insisted that the government "reserved the right" to use nuclear weapons if Britain or British troops deployed abroad were threatened by chemical or biological weapons." ${ }^{16}$ The problem for observers of the permutations in Hoon's thinking became discerning whether British policy had changed or whether Hoon's comments were cleverly meant to be deliberately "off-the-cuff" comments designed to enhance Britain's nuclear deterrent posture based on mutual assured destruction and/or preemption. 
The British government's December 2006 paper did not answer these questions unequivocally. The U.K. nuclear arsenal will continue to contain about 200 warheads, all carried on Trident II missiles based on Vanguard-class submarines, thus contributing, arguably, to a stable deterrent posture. ${ }^{17}$ The British government has also announced that it intends to begin work on a new generation of missile submarines to be deployed around $2025 .{ }^{18}$ While there is some opposition within the U.K. to this plan, ${ }^{19}$ the recent British Defense Paper is widely considered at NATO to be an unequivocal declaration of faith in Britain's continued reliance upon nuclear deterrence. ${ }^{20}$ Is the U.K intent upon possible preemptive use of nuclear weapons, as Hoon hinted so strongly? This is more difficult to figure out. British officers in charge of nuclear planning at NATO headquarters, in off-record comments, think that Hoon's style of issuing a deterrent threat was cleverer than the U.S. declared policy because it did not incite public discord or much discussion. They most fear an inharmonious debate within NATO circles of the implications of U.S. preemptive strategy for British and alliance nuclear policy. They believe the British and European general public's preference to rely upon the U.S. "ultimate" deterrent and Britain and France's "second lines of defense" mean that any discussion of possible "first use" of British nuclear weapons must be avoided.

British diplomats at NATO headquarters tend to think decisions to retain the Trident II missiles (and thus remain a nuclear weapon state) are consistent with Britain's essential support of classical nuclear deterrence. The opposite argument - that by renewing the Trident system, Britain has missed the opportunity to lead NATO toward denuclearization - is met with derision because, after all, in their widely shared view, Britain must never give up its independent reliance on its own nuclear deterrent. On the other hand, whether NATO should shape its official 
doctrine to reflect U.S. preemptive doctrine is a question brewing quietly in their own minds, but they are very reluctant to discuss it for fear of public dissension and domestic discord. ${ }^{21}$

\section{FRENCH NUCLEAR POLICY REMAINS DELIBERATELY AMBIGUOUS}

Although much smaller than the U.S. and Russian arsenals, France's nuclear arsenal is the world's third largest, containing about 350 warheads. The bulk of its arsenal is in the Force Océanique Stratégique. France is planning new warheads on new versions of its cruise and submarine launched missiles. In 2010-2015, four Triomphant-class submarines will be

retrofitted with the 6,000-km-range M51.1 submarine launched ballistic missile. ${ }^{22}$ At NATO headquarters, the French deterrent is referred to in common parlance as the French force de frappe and there is very little consideration of its implications for NATO policy.

In keeping with the change in U.S. policy, in November 2002, a French defense bill noted that "preemptive action is not out of the question where explicit and confirmed threats have been recognized." ${ }^{23}$ At NATO headquarters, the French delegation seems to remain focused on deterrence and prevention, but it is difficult for other delegations to discern their motives and understand their arguments. Repeatedly over the last decade, NATO diplomats from other delegations have indicated that they find the French approach and French diplomats to be deliberately ambiguous, more frustrating than even the Russians, and tremendously difficult to cope with at the committee level from a policy making perspective. Yet it seems evident that the concept of preemption, as related to "imminent threat," is now part of French strategy because of comments, among others, by a high-level diplomat in NATO's Nuclear Planning Group: 
The perfect example of someone who knew how to talk about deterrence effectively was Jacques Chirac in his great speech, was it last year? He was very good at making a statement that we have these weapons and if you attack us, we will use them. This is the essence of deterrence. . . . We can't say we'll never use them; this is the essential conundrum we face; the French made no bones about it and they even made claims of preemption in their speech. ${ }^{24}$

\section{NATO'S NUCLEAR POLICY REQUIRES ITS OWN STOCKPILE OF TACTICAL NUCLEAR WEAPONS}

NATO also has its own force of approximately 100 gravity bombs. These are commonly referred to as "sub-strategic" or "tactical nuclear weapons"- any term is sufficient. U.S. tactical nuclear weapons are deployed in six European NATO countries, five of which are non-nuclear weapon states (NNWS). All five-Belgium, Italy, Germany, the Netherlands, and Turkey ${ }^{25}$ have "nuclear-sharing" agreements with the U.S., under which they maintain aircraft equipped to carry nuclear weapons and pilots trained to deliver them. U.S. nuclear weapons under U.S. custody are stored in Europe for these aircraft. If a decision were made by NATO to use these weapons, they would be delivered by the air forces of these five supposedly non-nuclear weapon states. While the decision to use them would be ultimately the American President's, NATO forces train to use them and the nuclear warheads are spread upon the soil of the six NATO allies. Defense policy makers in Washington and Brussels who support deterrence argue that the NATO countries must retain these weapons, despite their relatively less importance, in order to show their commitment to the NATO alliance. Any talk of not upgrading the dual-capable 
weapons that would carry the tactical nuclear weapons cannot be tolerated as it is evidence of a weakening of the extended deterrent relationship. ${ }^{26}$

Once this complicated line of reasoning is understood - that there are essentially three levels of deterrence, with the ultimate deterrent being held by the United States - it is logical for defenders of deterrence to argue that NATO cannot disarm its tactical nuclear weapons as this would be seen as a weakening of the ultimate deterrent relationship with the United States. As one retired general explained, NATO cannot rid itself of its tactical nuclear weapons as this would be a "slippery slope" toward disarmament. ${ }^{27}$ In many ways, the tactical nuclear weapons exert a far more symbolic than tactically useful impact. Any weakening is shunned and the sentiment is repeated over and over again in all types of interviews with American and European decision makers, whether they are in NATO's Secretary-General's office or active in Washington or New York.

\section{U.S., FRENCh, AND BRITISH PREEMPTIVE DOCTRINES CONFLICT WITH NATO NUCLEAR POLICY}

There were some expectations that the U.S. might plausibly temper its preemptive doctrine in light of international criticism, and in light of the trend among the other NWS to develop similar preemptive doctrines. But members of the U.S. strategic policy and arms control communities in Washington were not particularly taken by surprise or perplexed by the U.S. decision in the spring of 2006 to reissue the basic elements of the National Security Strategy. The new concept of "preemptive" or "preventive" strategy that was reasserted in 2006 and continues to be the foundation of emerging U.S. nuclear doctrine is just now beginning to be 
considered at NATO headquarters in terms of its implications for NATO's Strategic Concept and nuclear nonproliferation.

Curiously, the leaders of the non-nuclear NATO countries continue to profess their reliance on the traditional strategy of nuclear deterrence while the U.S. moves toward a preemptive "first-strike" strategy that promises to retaliate with nuclear weapons, even in the event of a "limited" chemical or biological attack. The situation is similar to the late 1950s and 1960s when the allies continued to rely upon mutual assured destruction (MAD) even as the U.S. developed "flexible response." 28 To explain, the Strategic Concept links the NATO NNWS to the overall nuclear policies of the NATO nuclear weapon states (NWS) by asserting that, "The supreme guarantee of the security of the Allies is provided by the strategic nuclear forces of the Alliance, particularly those of the United States; the independent nuclear forces of the United Kingdom and France, which have a deterrent role of their own, contribute to the overall deterrence and security of the Allies." ${ }^{29}$ The Strategic Concept directly implicates the NATO NNWS in NATO's nuclear plans and force posture:

A credible Alliance nuclear posture and the demonstration of alliance solidarity and common commitment to war prevention continue to require widespread participation by European Allies involved in collective defence planning in nuclear roles, in peacetime basing of nuclear forces on their territory and in command, control and consultation arrangements. Nuclear forces based in Europe and committed to NATO provide an essential political and military link between the European and the North American members of the Alliance. The Alliance will therefore maintain adequate nuclear forces in Europe. $^{30}$ 
Recent interviews at NATO headquarters indicate some sort of in-depth review of NATO's nuclear doctrine, perhaps in time for NATO's sixtieth anniversary celebrations in 2009, may be forthcoming. Changes in nuclear doctrine can also be expected either preceding or in the wake of changes in the U.S. administration. ${ }^{31}$ Finally, we need to remember that efforts to change NATO's deterrent policy can begin at the nation-state level. ${ }^{32}$ The thrust for NATO's 1999 review essentially began because Canada's parliament released a report calling for a reexamination of NATO's reliance on nuclear deterrence and the Strategic Concept. ${ }^{33}$ Canada's former Foreign Minister Lloyd Axworthy committed his department to attempt to change NATO's nuclear doctrine—-for which he was often labeled a "nuclear nag." ${ }^{34}$ Working together with Joschka Fisher, the then German Foreign Minister, these critics of NATO policy attempted to persuade NATO diplomats that the alliance needed to reconsider its reliance on nuclear weapons for deterrence purposes. In the final analysis, even American diplomats at NATO headquarters were impressed with the Canadian/German initiative and the determination of the Canadian Foreign Minister and his diplomatic aides. ${ }^{35}$ In a similar fashion, working together with other like-minded "middle powers," such as Germany, Norway, Belgium, and the Netherlands, it might be possible to reforge NATO's nuclear doctrine. ${ }^{36}$ One option that is gaining popularity is the idea of strengthening the "moderate middle" of the debate among the non-nuclear weapon states in the UN and NATO. It will be especially important to do so as we move toward 2010 when there could be a significant weakening of the nuclear nonproliferation regime. 


\section{ENDNOTES}

1“Nuclear Posture Review (excerpts)," leaks to New York Times and Los Angeles Post were subsequently posted by the Global Security Institute at http://www.globalsecurity.org/wmd/library/policy/dod/npr.htm.

${ }^{2}$ US National Security Strategy: Prevent Our Enemies From Threatening Us, Our Allies, and Our Friends with Weapons of Mass Destruction, September 2002 available at www.state.gov/r/pa/ei/wh/15425.htm.

${ }^{3}$ US National Security Strategy: Prevent Our Enemies From Threatening Us, Our Allies, and Our Friends with Weapons of Mass Destruction, March 2006 available at http://www.state.gov/r/pa/ei/wh/15425.htm.

${ }^{4}$ Interview by author of Daryl Kimball, Executive Director, Arms Control Association, Washington, DC, April 24, 2006.

${ }^{5}$ Nuclear Age Peace Foundation, "The Challenge of Nuclear Weapons in the Twenty-First Century: A Path Forward,” June 15, 2003, http://waginpeace.org/articles/03.06/0613kireger_21century.htm. ${ }^{6}$ See Erika Simpson, NATO and the Bomb: Canadian Defenders Confront Critics, (Kingston \& Montreal: McGill-Queen's University Press), 2001 for analyses by high-level decision makers (e.g., U.S. Presidents, Canadian Prime Ministers, etc.) of how deterrence could fail due to misunderstanding, miscalculation, poor communication, irrational leadership, and accident. ${ }^{7}$ See Simpson, NATO and the Bomb. Sections of the book analyze the impact of bureaucratic recalcitrance on high-level decision making, including the effect of bureaucrats on efforts by Canadian prime ministers, such as Pierre Trudeau and foreign ministers like Lloyd Axworthy, to make changes in Canadian and NATO defense policy. 
${ }^{8}$ Quoted in Bob Woodward, Bush at War, (New York: Simon and Schuster), 2002, pp. 17-18

${ }^{9}$ Woodward, Bush at War, p. 228.

${ }^{10}$ Transcript: Second presidential debate," http://www.debates.org/pages/trans2004c.html.

${ }^{11}$ Simpson, NATO and the Bomb, ch. 8.

${ }^{12}$ Confidential interviews of high-level policymakers at NATO headquarters, April 2007.

${ }^{13}$ For further analysis, see Canadian Pugwash Group, "Canadian Pugwash Group Calls for

NATO to Denuclearize." This extensive June 2007 report is available at

http://www.pugwashgroup.ca/.

${ }^{14}$ Recent discussions of NATO's general nuclear doctrine are discussed in "Report on Options for Confidence and Security Building Measures (CSBMs), Verification, Nuclear Arms Control and Disarmament," December 2000, NATO Press Release 13 December 2000. For an analysis of NATO's nuclear sharing arrangements in Europe (e.g., the necessity to reduce or remove the U.S. tactical nuclear weapons based in Europe), see Karel Koster, "NATO Nuclear Doctrine and the NPT," BASIC Briefings and the Project on European Nuclear Non-Proliferation, Netherlands June 29, 2004, http://www.basicint.org/pubs/20040629NATO-nuclear-Koster.htm. As Koster explains, "If this withdrawal [of the U.S. nuclear weapons in Europe] were to be carried through, it would not necessarily imply a far-reaching change in nuclear doctrine. There is a clear distinction between withdrawing part (or even all) of the tactical weapons on the one hand, and abandoning NATO nuclear policy, on the other," p. 3.

${ }^{15}$ No author, “UK Prepared to Use Nuclear Weapons,” BBC News, March 20, 2002, http://news.bbc.co.uk/1/hi/uk_politics/1883258.stm. 
${ }^{16} \mathrm{He}$ made this claim on the Jonathan Dimbly program on ITV, quoted by Paul Rogers in his Witness Statement, Trident Ploughshares, May 2002, http://www.tridentploughshares.org/legal/devonpt4.php.

17 “'British Nuclear Forces, 2005,” Bulletin of the Atomic Scientists, November/December 2005, http://thebulletin.metapress.com/content/k52425n3320m8644/fulltext.pdf.

${ }^{18}$ The Future of the United Kingdom's Nuclear Deterrent, December 2006, http://www.mod.uk/NR/rdonlyres/AC00DD79-76D6-4FE3-91A16A56B03C092F/0/DefenceWhitePaper2006_Cm6994.pdf.

${ }^{19}$ Kate Hudson, “A Nuclear Shift on Trident?” New Statesman, 24 April 2007, http://www.newstatesman.com/200704240006.

${ }^{20}$ Confidential and off-record interviews by the author with high level U.K. policymakers in Vilnius, Lithuania at a NATO-sponsored high-level conference and at NATO headquarters in Brussels, April 2007.

${ }^{21}$ Ibid.

22 “French Nuclear Forces, 2005," Bulletin of the Atomic Scientists, July/August 2005, http://thebulletin.metapress.com/content/n8rn0x5567572723/fulltext.pdf.

${ }^{23}$ Confidential interview, NATO headquarters, Brussels, April 2007; see also Government of France, Defense Ministry, “Loi de Programmation Militaire 2003-2008,” September 11, 2002, pp. 24-25, www.defense.gouv.fr/english/files/d140/inde.htm. quoted in Francois Heisbourg, “A Work in Progress: The Bush Doctrine and Its Consequences," Washington Quarterly, 26(2) 2003, http://muse.jhu.edu/journals/washington_quarterly/v026/26.2heisbourg.html.

${ }^{24}$ Interview by the author of high-level American diplomat in charge of NATO's Nuclear Planning Group, April 2007. 
${ }^{25}$ For more information on NATO nuclear weapons and "nuclear-sharing" arrangements, see Hans M. Kristensen, U.S. Nuclear Weapons in Europe, Natural Resources Defense Council, February 2005, http://www.nrdc.org/nuclear/euro/contents.asp.

${ }^{26}$ For example, this basic sentiment was strongly expressed among the International Staff at NATO headquarters by Jamie Shea, Michael Ruhle, Guy Roberts, Robert Simmons, and Ted Whiteside in April 2007.

${ }^{27}$ Confidential interview by the author of retired American general involved in NATO doctrinal planning, Washington, DC, April 2006.

${ }^{28}$ For more information, see Erika Simpson, NATO and the Bomb: Canadian Defenders Confront Critics, (Kingston \& Montreal: McGill-Queen's University Press), 2001, ch. 3.

29 “The Alliance's Strategic Concept," para. 62.

30 “The Alliance's Strategic Concept," para. 63.

${ }^{31}$ Confidential interviews by the author of Dr. Guy Roberts, Director of the Nuclear Policy

Directorate, Defesce Policy and Planning Division, NATO headquarters, April 23, 2007 and Dr. Michael Ruhle, Head, Speechwriting \& Senior Policy Adviser, Policy Planning Unit, Private Office of the Secretary General, NATO headquarters, April 24, 2007, NATO headquarters, Brussels.

${ }^{32}$ Erika Simpson. "New Threats to the Alliance's Security and Strategies to Reform NATO," The Transatlantic Quarterly, Winter/Spring 2005, pp. 47-51.

${ }^{33}$ Government of Canada, Report of the Standing Committee on Foreign Affairs and International Trade, "Canada and the Nuclear Challenge: Reducing the Political Value of Nuclear Weapons for the Twenty-First Century," (Ottawa: Publications Service), December 1998. See also Erika Simpson, “Canada’s NATO Commitment: Current Controversies, Past 
Debates, and Future Issues," Behind the Headlines, Vol. 57, No. 2/3, winter/spring 2000, pp. 20-

27.

${ }^{34}$ Senator Douglas Roche, Chairman, Canadian Pugwash Group and Ernie Regehr, Executive Director, Project Ploughshares, "Canada, NATO and Nuclear Weapons," Toronto, March 17, 2001, http://www.sen.parl.gc.ca/droche/writings/documents/nuclear/cannatonw.pdf.

${ }^{35}$ Interview by the author with Canada's Deputy Ambassador to NATO, Robert McCrae, February 2001 and off-record comments by senior members of the U.S. Delegation to NATO, February 2001.

${ }^{36}$ No author, "Nonproliferation and Disarmament Go Hand in Hand," International Herald Tribune, September 22, 2004.

\section{REFERENCES}

Canadian Pugwash Group, “The Only Absolute Guarantee," April 2003, pp. 4-6, http://www.pugwash.org/reports/nw/canada-april2003.

Canadian Pugwash Group, "Canadian Pugwash Group Calls for NATO to Denuclearize," http://www.pugwashgroup.ca/

Government of Canada, Report of the Standing Committee on Foreign Affairs and International Trade, "Canada and the Nuclear Challenge: Reducing the Political Value of Nuclear Weapons for the Twenty-First Century," (Ottawa: Publications Service), December 1998. 
Heisbourg, Francois. “A Work in Progress: The Bush Doctrine and Its Consequences,” Washington Quarterly, 26(2) 2003, http://muse.jhu.edu/journals/washington_quarterly/v026/26.2heisbourg.html.

Hudson, Kate. “A Nuclear Shift on Trident?” New Statesman, 24 April 2007, http://www.newstatesman.com/200704240006.

Koster, Karel. "NATO Nuclear Doctrine and the NPT," BASIC Briefings and the Project on European Nuclear Non-Proliferation, Netherlands June 29, 2004, http://www.basicint.org/pubs/20040629NATO-nuclear-Koster.htm.

Kristensen, Hans. M. U.S. Nuclear Weapons in Europe, Natural Resources Defense Council, February 2005, http://www.nrdc.org/nuclear/euro/contents.asp.

NATO, "Report on Options for Confidence and Security Building Measures (CSBMs), Verification, Nuclear Arms Control and Disarmament," December 2000, NATO Press Release, 13 December 2000.

No author, "UK Prepared to Use Nuclear Weapons," BBC News, March 20, 2002, http://news.bbc.co.uk/1/hi/uk_politics/1883258.stm.

No author, "British Nuclear Forces, 2005," Bulletin of the Atomic Scientists, November/December 2005, http://thebulletin.metapress.com/content/k52425n3320m8644/fulltext.pdf.

No author, "French Nuclear Forces, 2005," Bulletin of the Atomic Scientists, July/August 2005, http://thebulletin.metapress.com/content/n8rn0x5567572723/fulltext.pdf.

No author, "Nonproliferation and Disarmament Go Hand in Hand," International Herald Tribune, September 22, 2004. 
Nuclear Age Peace Foundation, "The Challenge of Nuclear Weapons in the Twenty-First Century: A Path Forward," June 15, 2003, http://waginpeace.org/articles/03.06/0613krieger_21century.htm.

Rogers, Paul. "Witness Statement, Trident Ploughshares,” May 2002, http://www.tridentploughshares.org/legal/devonpt4.php.

Roche, Senator Doug. Chairman, Canadian Pugwash Group and Ernie Regehr, Executive Director, Project Ploughshares, “Canada, NATO and Nuclear Weapons," Toronto, March 17, 2001, http://www.sen.parl.gc.ca/droche/writings/documents/nuclear/cannatonw.pdf.

Simpson, Erika. NATO and the Bomb: Canadian Defenders Confront Critics, (Kingston \& Montreal: McGill-Queen's University Press), 2001.

Simpson, Erika. "Threats to the Nuclear Non-Proliferation Treaty," News in Review, UN Headquarters, NYC, Issue No. 14, May 19, 2005, pp. 4-5.

Simpson, Erika. 'New Threats to the Alliance's Security and Strategies to Reform NATO,” The Transatlantic Quarterly, Winter/Spring 2005, pp. 47-51.

Simpson, Erika. “Canada’s NATO commitment: Current Controversies, Past Debates, and Future Issues," Behind the Headlines, Vol. 57, No. 2/3, winter/spring 2000, pp. 20-27.

“Transcript: Second Presidential Debate," 2004, http://www.debates.org/pages/trans2004c.html.

United Kingdom government, The Future of the United Kingdom's Nuclear Deterrent, December 2006, http://www.mod.uk/NR/rdonlyres/AC00DD79-76D6-4FE3-91A16A56B03C092F/0/DefenceWhitePaper2006_Cm6994.pdf. 
U.S. Government, "National Security Strategy: Prevent Our Enemies From Threatening Us, Our Allies, and Our Friends with Weapons of Mass Destruction” September 2002, http://www.state.gov/r/pa/ei/wh/15425.htm.

"U.S. National Security Strategy: Prevent Our Enemies From Threatening Us, Our Allies, and Our Friends with Weapons of Mass Destruction," March 2006, http://www.state.gov/r/pa/ei/wh/15425.htm

U.S. Government, "Nuclear Posture Review," excerpts from the secret document were posted by the Global Security Institute at http://www.globalsecurity.org/wmd/library/policy/dod/npr.htm.

Woodward, Bob. Bush at War (New York: Simon and Schuster), 2002. 